\title{
KONSTRIBUSI KEBIJAKAN DESENTRALISASI PENDIDIKAN TERHADAP LEMBAGA PENDIDIKAN ISLAM DI KOTA PALOPO
}

\section{A CONTRIBUTION OF EDUCATIONAL DECENTRALIZATION POLICY TO ISLAMIC EDUCATION INSTITUTIONS AT PALOPO CITY}

\author{
Hisban \\ Institut Agama Islam Negeri Palopo \\ Jl. Agatis Balandai Kota Palopo \\ Email: xhavier.wiaam@gmail.com
}

Naskah diterima tanggal 4 Oktober 2017. Naskah direvisi 18 Oktober 2017. Naskah disetujui 30 Oktober 2017.

\begin{abstract}
Abstrak
Penelitian ini bertujuan untuk membahas pelaksanaan kebijakan desentralisasi dalam bidang pendidikan di Kota Palopo, dan untuk menggambar kontribusi kebijakan tersebut pada lembaga pendidikan Islam di Kota Palopo. Metode yang digunakan dalam penelitian ini bersifat diskriptif kualitatif, menggunakan beberapa jenis pendekatan, yaitu: teologis, pedagogis, historis, sosiologis. Studi ini menggunakan dua jenis sumber data, yaitu bersifat data primer dan sekunder. Adapun pengumpulan data menggunakan empat macam teknik, yaitu: : (1) Observasi, (2) Wawancara, (3) Dokumentasi. (4) Triangulasi. Adapun teknik analisis data melalui proses tahapan-tahapan sebagai berikut: (1) Pengumpulan data (data interactive), (2) Reduksi data (data reduction), (3) Penyajian data (data display), dan (4) Penarikan kesimpulan (conclusion drawing and verification). Hasil Studi menunjukkan, bahwa desentralisasi pendidikan di Kota Palopo telah berlangsung sesuai prosedur dan mekanisme yang ada. Kebijakan ini memberikan pengaruh yang cukup besar bagi peningkatan layanan dan mutu pendidikan. Kebijakan ini juga memberikan kontribusi yang positif dan berarti bagi lembaga pendidikan Islam formal di Kota Palopo. Dalam beberapa hal masih ditemukan kebijakan yang terkesan diskriminatif terhadap lembaga pendidikan Islam terutama dalam kaitannya dengan subsidi sarana-prasarana, distribusi ketenagaan dan kesejahteraan.
\end{abstract}

Kata kunci: kontribusi, desentralisasi, lembaga pendidikan, Palopo

\begin{abstract}
This Study aims to discuss the implementation of educational decentralization policy at Palopo City and to describe its contribution to Islamic Education Institutions at Palopo City. This research is a qualitative study, using some approaches; theology, paedagogy, history, sociology. This study uses two kinds of data sources, they are primary data and secondary data. Data were collected by means of four ways, such as: observation, interview, documentation, and triangulation. The data were analized through several process, such as: data interactive, data reduction, data display, and conclusion drawing and verification. The result of study indicates that the educational decentralization policy at Palopo City has been well implemented regarding the existing procedure and mechanism. This policy has contributed to the quality of service and educational system. This policy has also provided positive contribution to Islamic education institution at Palopo City. Inspite of the positive contribution, it was found that there have been discrimination of the implementation of educational decentralization policy to Islamic Education such as, infrastructure, distribution of employee, and salary.
\end{abstract}

Keywords: contribution, decentralization, institution of education, Palopo

\section{PENDAHULUAN}

$\mathrm{D}$ inamika perjalanan pendidikan nasional telah melampaui masa yang sangat panjang dandewasa ini telah mencapai fase demokratis, yang ditandai dengan lahirnya kebijakan desentralisasi di bidang pendidikan. Tujuannya adalah untuk meningkatkan performance dan akselerasi pencapaian tujuan pendidikan nasional itu sendiri (Jamaluddin, 2001: 140).

Dalam Undang-Undang RI No. 32 Tahun 2004 ditegaskan bahwa terkait dengan otonomi daerah 
terdapat beberapa kewenangan pusat diserahkan kepada daerah untuk penyelenggaraannya termasuk bidang pendidikan. Dalam UndangUndang tersebut (pasal 12 dan pasal 14) dinyatakan bahwa pemerintah Kabupaten/Kota dituntut untuk mengelola program pendidikan dengan baik dan bertanggungjawab.

Sebagai sebuah kebijakan pembangunan nasional di bidang pendidikan, sistem desentralisasi pendidikan pada setiap daerah adalah suatu kemutlakan yang harus diimplementasikan secara bertahap dan menyeluruh pada semua jenjang dan jenis lembaga pendidikan, termasuk pendidikan Islam.

Berkenaan dengan eksistensi pendidikan agama, dalam Undang-Undang RI No. 20 Tahun 2003 pasal 14-16, secara eksplisit dijelaskan kesetaraan posisi semua jenis pendidikan. Kesetaraan yang dimaksud secara tegas dinyatakan bahwa tidak terdapat lagi perlakuan dikotomis dan diskriminatif antara jenis pendidikan umum dan pendidikan agama serta jenis pendidikan lainnya. Perlakuan tersebut tidak hanya dalam aspek tertentu melainkan secara holistik, termasuk aspek pembinaan dan penganggaran dan seterusnya, serta penyelenggaraannya dilakukan secara desantralistik.

Berangkat dari argumen di atas, peneliti mencoba melakukan penelitian untuk memastikan apakah pesan substantif undang-undang tersebut telah dilaksanakan pada tingkat daerah seiring dengan diberlakukannya sistem pemerintahan otonomi daerah. Berdasarkan studi awal peneliti mengenai kebijakan pemerintah Kota Palopo dalam bidang pendidikan, diperoleh gambaran bahwamasih terjadi perlakuan dikriminatif terhadap lembaga pendidikan Islam (madrasah dan pesantren) di dalam penerapan kebijakan tersebut. Hal ini dapat terlihat dalam beberapa hal, antara lain pada distribusi bantuan sarana-prasarana, anggaran, penempatan guru, kesejahteraan, pengawasan dan sebagainya.

\section{Tinjauan Pustaka}

Husen dan Postlethwaite mendefinisikan desentralisasi pendidikan sebagai "the devolution of authority from to higher level of government, such as a departement or lokal education authority, to a lower organizational level, such as individual school." (Prawira, 2012: 3) Senada dengan itu, Bray dan Fiske (dalam Depdiknas, 2001: 3) mendefinisikan, desentralisasi pendidikan adalah suatu proses dimana suatu lembaga yang lebih rendah kedudukannya menerima pelimpahan kewenangan untuk melaksanakan segala tugas pelaksanaan pendidikan, termasuk pemanfaatan segala fasilitas yang ada serta penyusunan kebijakan dan pembiayaan .

Tilaar (Syafruddin, 2005: 280-281) dalam memahami otonomi pendidikan berarti: pertama, sebagai upaya menata kembali sistem pendidikan nasional yang sentralistis menuju kepada suatu sistem yang memberikan kesempatan luas kepada inisiatif masyarakat. Otonomi pendidikan berarti pula demokratisasi sistem pendidikan yang berarti mengem-balikan hak dan kewajiban masyarakat untuk mengurus pendidikannya; kedua; otonomi pendidikan berarti memperkuat dasar-dasar pendidikan pada tingkat grass-root untuk membentuk suatu masyarakat Indonesia yang bersatu berdasar-kan kebhinnekaan masyarakat, atau dengan kata lain pendidikan dikembalikan kepada the stake holders ialah masyarakat itu sendiri. Jadi, desentralisasi pendidikan ialah pendelegasian sebagian atau seluruh wewenang di bidang pendidikan yang seharusnya dilakukan oleh pejabat pusat atau pejabat di bawahnya atau dari pemerintah pusat kepada pemerintah daerah atau dari pemerintah kepada masyarakat.

Secara konseptual desentralisasi pendidikan terdiri atas dua jenis, yaitu: pertama, desentralisasi dalam arti kewenangan di sektor pendidikan dalam hal kebijakan pendidikan dan aspek pendanaannya dari pemerintah pusat ke pemerintah daerah; kedua, desentralisasi pendidikan dengan fokus pada pemberian kewenangan yang lebih besar kepada sekolah (Alisyahbana, 2000: 2).

Sebelum otonomi, peran pemerintah sangat dominan. Hampir semua aspek dari pendidikan diputuskan kebijakan dan perencanaannya di tingkat pusat, sehingga daerah terkondisikan lebih hanya sebagai pelaksana. Pendidikan dikelola tanpa mengembangkan kemampuan kreativitas masyarakat, malah cenderung meniadakan partisipasi masyarakat di dalam pengelolaan pendidikan. Lembaga pendidikan terisolasi dan tanggung jawab sepenuhnya ada pada pemerintah pusat. Sedangkan masyarakat tidak mempunyai wewenang untuk mengontrol jalannya pendidikan. Selain itu, dengan sendirinya orang tua dan masyarakat, sebagai konstituen dari sistem pendidikan nasional yang terpenting, telah kehilangan peranannya dan tanggung jawabnya. 
Sesudah otonomi, ada perluasan peluang bagi peran serta masyarakat dalam pendidikan baik secara kualitatif maupun kuantitatif. Oleh karena itu, untuk mendorong partisipasi masyarakat, di tingkat Kabupaten/Kota dibentuk Dewan Pendidikan, sedangkan di tingkat sekolah dibentuk komite sekolah. Pembentukan komite sekolah didasarkan pada keputusan Mendiknas No.044/U/2002 tentang panduan pembentukan komite sekolah. Menurut panduan, pembentukan komite sekolah dilakukan secara transparan, akuntabel, dan demokratis. Jadi, cakupan desentralisasi pendidikan tidak hanya pemberian kewenangan penganggaran, tetapi juga penentuan kebijakan pada kurikulum dan halhal lain yang berkaitan dengan pengembangan pendidikan. Demikian pula kewenangan itu bukan hanya milik pemerintah daerah tetapi juga bagi sekolah dan bahkan komunitas pemerhati pendidikan atau dewan pendidikan.

Abdurrahmansyah (2005: 156) mengatakan bahwa secara umum desentralisasi pendidikan kategori ini berada dalam dua kawasan, yaitu desentralisasi persekolahan (pendidikan dasar dan menengah) dan otonomi perguruan tinggi. Untuk kategori persekolahan dikenal istilah School Based Management atau Management Berbasis Sekolah (MBS), sedangkan bagi perguruan tinggi dengan sistem pengelolaan Badan Hukum Milik Negara (BHMN), Badan Layanan Umum (BLU) dan privatisasi.

Dalam anatomi dan struktur UndangUndang Nomor 32 Tahun 2004 dicantumkan pendidikan termasuk bidang kewenangan yang diberikan kepada daerah dan bahkan termasuk bidang pemerintahan yang wajib dilaksanakan oleh Pemerintah Daerah Kabupaten dan Kota.

Kewenangan pemerintah daerah untuk mengelola pendidikan secara desentralistik secara ekslusif disebutkan dalam Undang-Undang RI No. 20 Tahun 2003 tentang Sistem Pendidikan Nasional Pasal 10 dan 11 mengenai hak dan kewajiban pemerintah dan pemerintah daerah dalam hal penyelenggaraan pendidikan, sebagai berikut: Pemerintah dan Pemerintah Daerah berhak mengarahkan, membimbing, membantu, dan mengawasi penyelenggaraan pendidikan sesuai dengan peraturan perundang-undangan yang berlaku.

Pemerintah dan Pemerintah Daerah wajib memberikan layanan dan kemu-dahan, serta menjamin terselenggaranya pendidikan yang bermutu bagi setiap warga negara tanpa diskriminasi.
Dari keterangan tersebut, secara tegas menyatakan bahwa kewenangan penyelenggaraan pendidikan adalah merupakan tanggungjawab bersama pemerintah pusat dan daerah. Pemerintah daerah dengan hak otonominya dapat menyelenggarakan pendidikan sesuai kehendak dan potensinya.

Menurut Edward B.Fiske, seperti dikutip oleh Abdurrahmansyah (2005: 149-150), sekurangkurangnya ada empat alasan rasional diterapkannya sistem desentralisasi sebagai sistem penyelenggaraan sistem sosial, termasuk pendidikan. Pertama, alasan politis, yakni untuk mempertahankan stabilitas dalam rangka memperoleh legitimasi pemerintah pusat dari masyarakat daerah, sebagai wujud penerapan ideologi sosialis dan laissez-faire dan untuk menumbuhkan kehidupan demokrasi. Kedua, alasan sosio-kultural, yakni untuk memberdayakan potensi masyarakat lokal. Ketiga, alasan teknis-administratif dan paedagogis seperti pemangkasan manajemen lapisan tengah agar dapat membayar gaji guru tepat waktu atau untuk meningkatkan antusiasme guru dalam proses belajar me-ngajar. Keempat, alasan ekonomis-finansial seperti meningkatkan sumber daya tambahan untuk pembiayaan pendidikan dan sebagai alat pembangunan ekonomi.

Terlepas dari plus-minus dan pro-kontra pemberlakuan kebijakan desentralisasi dalam bidang pendidikan ini, pada prinsipnya kebijakan ini mengarah kepada suatu perbaikan pendidikan yang sangat substansial yang pada gilirannya diharapkan dapat memberikan implikasi yang signifikan dan mendasar pada kandungan, proses, dan manajemen sistem pendidikan secara nasional. Selain itu juga, hal ini menunjukkan political will pemerintah pusat untuk mendorong terwujudnya demokrasi, keragaman dan partisipasi masyarakat dalam pendidikan.

Adapun tujuan desentralisasi pendidikan setidaknya adalah bertujuan untuk mengurangi campur tangan atau intervensi pejabat atau unit pusat terhadap persoalan pendidikan yang sepatutnya bisa diputuskan dan dillaksanakan oleh unit tataran bawah atau masyarakat (Miftah, 1999: 1-7). Dengan demikian desentralisasi pendidikan ini juga bertujuan untuk membudayakan peranan unit bawah atau masyarakat dalam menangani persoalan pendidikan di bawah. Oleh karena itu, dalam konsep desentralisasi pendidikan ini terdapat tiga nilai yang ingin diubah dalam sektor pendidikan, sebagai berikut: pertama, sebagai 
upaya untuk mendekatkan pengambilan keputusan yang selama ini terlalu jauh. Kedua, untuk menyesuaikan pembangunan pendidikan agar lebih sesuai dengan kekhasan daerah. Ketiga, untuk lebih mendayagunakan potensi masyarakat yang sangat besar. Ketiga value ini diharapkan dapat meningkatkan peranan pendidikan dalam kaitannya dengan peningkatan mutu dan relevansi, efisiensi manajemen dan pemerataan akses pendidikan bagi seluruh lapisan masyarakat.

Salah satu makna substansif yang terkandung dalam gerakan reformasi adalah pelimpahan kewenangan yang bersifat sentralistik ke arah desentralistik. Kebijakan dan kewenangan pelimpahan wewenang ini dari pusat ke daerah disebut dengan istilah otonomi daerah atau desentralisasi. Sebagai disebutkan sebelumnya bahwa ruang lingkup desentralisasi ini mencakup berbagai aspek dalam kehidupan berbangsa dan bernegara, termasuk bidang pendidikan.

Wujud komitmen pemerintah pusat dalam bidang pendidikan terkait reformasi di bidang pendidikan ini, sebagaimana dijelaskan pada bagian terdahulu adalah dengan lahirnya berbagai macam kebijakan dalam bentuk undang-undang dan aturan-aturan yang merupakan turunanannya.

Dalam era otonomi daerah beberapa perubahan terjadi dalam bidang pendidikan termasuk pendidikan Islam, yaitu:

\section{Pengelolaan pendidikan yang lebih bersifat demokratis}

Di dalam Undang-Undang RI Nomor 20 Tahun 2003 bab IV pasal 8 dan 9 tentang hak dan kewajiban masyarakat disebutkan, sebagai berikut:

Masyarakat berhak berperan serta dalam perencanaan, pelaksanaan, pengawasan, dan evaluasi program pendidikan. Masyarakat berkewajiban memberikan dukungan sumber daya dalam penyelenggaraan pendidikan

Diktum Undang-Undang di atas secara eksplisit menjelaskan bahwa merupakan bagian sangat terpenting dalam desentralisasi pendidikan ini adalah terjadinya perubahan pengelolaan pendidikan yang bersifat demokratis, dalam arti pada tataran penyelenggara pendidikan lebih dipertegas lagi dari kebijakan sebelumnya, bahwa tanggung jawab penyelenggaraan pendidikan, bukan hanya merupakan tanggung jawab, kewajiban dan otoritas penuh pemerintah atau kelompok tertentu, akan tetapi telah menjadi hak, tanggung jawab dan kewajiban yang diberikan dan dibebankan kepada semua pihak untuk ikut berpartisifasi secara aktif dalam tahapan dan proses penyelenggaraan pendidikan. Dengan demikian, kelompok masyarakat memiliki pula hak untuk menyelenggarakan pendidikan dengan berbagai jenis dan bentuknya, sebagai bagian penunaian kewajiban dalam mencerdaskan kehidupan bangsa atau lebih dikenal dengan istilah pendidikan berbasis masyarakat. Jenis dan bentuk pendidikan yang terakomodir dalam perundang-undangan tersebut tidak hanya dalam bentuk persekolahan tetapi juga dalam bentuk lain yang merupakan institusi yang melibatkan partisipasi masyarakat dalam rangka mencerdaskan kehidupan bangsa seperti pesantren dan kegiatan-kegiatan lain yang dilakukan secara terstruktur.

Lebihjauhdaripadaitu,pada erainipemerintah telah menetapkan kebijakan dalam hal penguatan peran sekolah yang membuat sekolah maupun madrasah lebih fokus dan memiliki perencanaan yang lebih baik. Kebijakan dimaksud antara lain, kurikulum berbasis sekolah, manajemen berbasis sekolah (MBS), yang bermakna pendelegasian hak kepada sekolah dalam pengambilan keputusan dan mengembangkan lembaganya.

\section{Penguatan Pendidikan Islam}

Sebagaibagian darisistempendidikan nasional, pendidikan Islam khususnya madrasah yang secara eksplisit disebutkan dalam sistem pendidikan nasional, maka keberadaan madrasah semakin menjadi kuat baik secara legalistik formal, maupun dalam aspek pembinaan dan pengembangannya. Oleh karena itu, untuk mengadaptasi amanah yang tertuang dalam setiap aturan dan perundangundangan serta kebijakan pendidikan nasional yang terjadi pada periode ini, Kementerian Agama selaku institusi penanggung jawab yang membidangi pendidikan Islam melakukan berbagai usaha dan program baik berupa kegiatan baru, maupun dalam bentuk usaha penajaman program, antara lain yang dapat dikemukakan adalah:

\section{Penajaman visi-misi madrasah.}

Pada era ini, visi dan misi pendidikan madrasah lebih dipertajam yakni diharapkan dapat mewujudkan insan Indonesia yang memiliki sikap agamis, berkemampuan ilmiah yang amaliah, amaliah yang ilmiah, terampil dan profesional. Oleh karena itu, maka materi ajar yang dikemas dalam kurikulum diarahkan kepada upaya untuk menjadikan peserta didik yang memiliki ilmu yang 
setinggi-tinggi dengan dilandasi oleh nilai moral keagamaan yang kuat (Zayadi, 2005: 12).

Untuk mengakselerasi terwujudnya visi-misi dan meningkat-kan mutu pendidikan madrasah, dilakukan berbagai upaya dan kebijakan, antara lain: 1) penyempurnaan kurikulum, 2) pengadaan buku dan bahan ajar, 3) peningkatan guru dan tenaga kependidikan, 4) peningkatan manajemen pendi-dikan, dan 5) peningkatan sarana dan sarana pendidikan (Departemen Agama RI, 2005: 1).

\section{Pembentukan community based education}

Salah satu model pembinaan pendidikan dalam era otonomi daerah adalah pelibatan masyarakat secara langsung dalam pengelolaan pendidikan. Masyarakat sebagai pemangku kepentingan pendidikan diberi kewenangan untuk bersama-sama dengan pemerintah merumuskan kebijakan pendidikan dari hulu sampai ke hilir, yakni mulai dari perencanaan, pelaksanaan, pengawasan, evaluasi dan bahkan arah pendidikan yang diinginkan. Partisipasi aktif dalam kebijakan pendidikan inilah yang kemudian disebut dengan istilah "community based education" yang berarti pendidikan berbasis masyarakat (Malla, tth: 406).

Di era sebelumnya, secara konsepsional eksistensi lembaga pendidikan Islam, khususnya madrasah telah memiliki posisi kesetaraan dengan lembaga pendidikan umum, namun nuansa diskriminasi dan kecanggungan dalam tataran implementasinya masih sangat terasa. Hal ini disebabkan oleh karena pelibatan aktif masyarakat belum maksimal, sosialisasi paradigma baru tentang eksistensi madrasah baru bergulir, serta kecenderungan masyarakat terhadap perubahan kebijakan pada madrasah masih terbelah, sebagian setuju dengan model yang lama dan yang lainnya setuju dengan model yang baru.

Menyadari akan hal ini, pada era otonomi daerah ini peran masyarakat dalam pengembangan madrasah semakin diintensifkan yakni pemerintah (daerah) bersama dengan stakeholder atau masyarakat pemangku kepentingan pendidikan melakukan desain pengembangan yang relevan dengan konteks otonomi pendidikan dalam hal: 1) strategi peningkatan layanan pendidikan madrasah, 2) strategi perluasan dan pemerataan kesempatan pendidikan di madrasah; 3) strategi peningkatan mutu dan relevansi pendidikan di madrasah; 4) strategi pengembangan manajemen pendidikan madrasah; dan 5) strategi pember-dayaan kelembagaan di madrasah (Zayadi, 2005: 38). Hal ini dilakukan dengan tujuan untuk meningkatkan mutu kinerja, proses pembelajaran, pengelolaan sumber belajar, profesionalisme tenaga kependidikan dan sistem adminsitrasi madrasah secara keseluruhan. Pola pengembangan sebagaimana dikemukakan di atas sangat ideal karena memosisikan masyarakat selaku pemangku kepentingan sebagai subyek dan obyek pendidikan.

\section{Pengembangan kurikulum}

Sebagai konsekwensi dari perubahan sistem pendidikan nasional dan dinamika kemauan ilmu pengetahuan dan teknologi, maka desain kurikulum pendidikan pada persekolahan harus selalu mengalami pengadaptasian. Hal ini terjadi pada semua lembaga pendidikan termasuk pendidikan Islam formal, khususnya lembaga pendidikan formal yang berada di bawah naungan peme-rintah. Hal yang sama juga terjadi pada pondok-pondok pesantren atau lembaga pendidikan masyarakat yang mengasuh madrasah atau persekolahan.

Secara periodik, pendidikan di Indonesia telah mengalami beberapa kali perubahan dan penyempurnaan kurikulum. Untuk era otonomi pendidikan saja telah mengalami dua kali perubahan kurikulum, yaitu Kurikulum Berbasis Kompetensi (KBK) dan Kurikulum Tingkat Satuan Pendidikan (KTSP).Terlepas dari kekhususan yang membedakan kedua bentuk kurikulum tersebut, keduanya memiliki ciri yang sama yakni desain kurikulum terintegrasi (integrated curriculum) dan menonjolkan pola pembelajaran student-centred, disertai model-model pembelajaran kreatif.

\section{Pengembangan Kelembagaan}

Sejak era orde baru dan orde reformasi telah terjadi perubahan pandangan dan orientasi kebijakan pemerintah terhadap eksistensi pendidikan Islam secara signifikan. Dan yang demikian itu semakin terasa perubahannya ketika memasuki era otonomi daerah. Pengembangan kelembagaan pendidikan Islam terutama madrasah mengalami perubahan yang cukup signifikan. Hal ini ditandai dengan dilakukannya perubahan desain madrasah. Oleh Direktorat Pendidikan Islam Departemen Agama RI mengembangkan tiga model madrasah,yaitu: 1) madrasah unggulan yang ditempatkan pada setiap daerah provinsi; 2) madrasah model yang ditempatkan di setiap daerah kabupaten/kota; dan 3) madrasah reguler dan kejuruan yang didirikan di setiap tempat sesuai dengan kebutuhan masyarakat (Malla, t.th: 205). Kebijakan pendirian madrasah dengan berbagai 
variasinya ini dengan menggunakan pendekatan dan pertimbangan di atas adalah dimaksudkan untuk mengakselerasi agar supaya pendidikan Islam dapat menjadi pusat unggulan (centre of excelence) tidak hanya dalam ilmu-ilmu agama tetapi juga ilmu-ilmu umum. Selain itu juga diharapkan dapat menjadi lembaga pendidikan prioritas dan alternatif yang mudah diakses oleh masyarakat.

\section{METODE PENELITIAN}

Penelitian ini dilakukan dalam wilayah hukum Kota Palopo Provinsi Sulawesi Selatan. Pemilihan wilayah ini sebagai lokasi penelitian didasarkan atas pertimbangan, (a) bahwa wilayah ini adalah salah satu daerah tujuan pendidikan di Provinsi Sulawesi Selatan. Memiliki belasan perguruan tinggi dan puluhan sekolah menengah atas.(b) Lokasi penilitian telah menerapkan kebijakan desentralisasi pendidikan secara serius dan konsisten, baik pada tingkat pemerintah daerah maupun tingkat sekolah. c) Selain itu, yang tidak kalah pentingnya adalah Kota Palopo adalah sentra daerah yang ada di Tana Luwu Raya dan daerah kabupaten sekitarnya, dan juga merupakan salah satu wilayah penyebaran Islam pertama di Sulawesi-Selatan dan juga memiliki lembaga pendidikan Islam formal yang jumlahnya cukup signifikan dengan berbagai jenis dan tingkatannya.

Dalam konteks penelitian ini, peneliti menetapkan lembaga pendidikan Islam yang menjadi obyek penelitian, yaitu: Madrasah Ibtidaiyah Darud Da'wah wal Irsyad I (MI DDI I) Palopo mewakili lembaga pendidikan Islam swasta, Sekolah Menengah Pertama (SMP) dan Sekolah Menengah Atas (SMA) Pesan-tren Modern Datok Sulaiman (PMDS) Palopo mewakili lembaga pendidikan Islam swasta yang berciri khusus. Penelitian ini menggunakan pendekatan Pedagogis, Historis, Sosiologis, dan Kebijakan.

Dalam kegiatan pengumpulan data, peneliti menggunakan beberapa instrumen yang sesuai metode atau jenis kegiatan yang dilakukan dalam menjaring semua data yang dibutuhkan, antara lain: Pedoman wawancara, Buku atau lembaran catatan lapangan, Slip, alat perekam dan kartu kutipan.

Dalam kaitan penelitian ini, peneliti melakukan proses analisis data pada dua tahapan kegiatan yaitu: analisis sebelum di lapangan dan analisis selama di lapangan. Peneliti melakukan langkah-langkah analisis sebagai berikut: Pertama, tahap pengumpulan data, Kedua, tahap reduksi data (data reduction), yaitu data yang telah terkumpul kemudian direduksi. Ketiga, tahap penyajian data (data display). Keempat, tahap penarikan kesimpulan dan verifikasi (conclusion drawing and verifikation). Dalam rangka uji keabsahan data, peneliti melakukan langkah-langkah, yaitu: Perpanjangan pengamatan, Peningkatan ketekunan, Triangulasi, Analisis Kasus Negatif, Mengadakan member check.

\section{PEMBAHASAN}

\section{Pelaksanaan Desentralisasi Pendidikan di Kota Palopo}

Desentralisasi pendidikan di Kota Palopo dimulai seiring dengan pemekaran dan penetapan Kota Palopo sebagai Kota Otonom berdasarkan Undang-Undang Nomor 11 Tahun 2002, yang tertuang di dalam Lembaran Negara Tahun 2002 Nomor 25, Tambahan Lembaran Negara Nomor 4168. Sejak pelaksanaan desentralisasi pendidikan pemerintah daearah kota Palopo telah menetapkan 2 kali PerdaPendidikan, yaitu Perda Nomor 11 Tahun 2008 dan Perda Nomor 2 Tahun 2013. Pada tataran implementasi dan penyusunan program, pelaksanaan dan evaluasi, pemerintah kota mengusung visi dan misi yakni ingin mewujudkan Palopo sebagai Kota Pendidikan.

Untuk itu, Pemerintah Daerah Kota Palopo menetapkan prorram kebijakanpembangunan di bidang pendidikan, paling tidak 6 agenda pokok, yaitu meliputi: penguatan dan pengembangan Kelembagaan, penjaminan mutu dan akreditasi, pengembangan sarana dan prasarana, pengembangan SDM dan profesi guru, pengelolaan anggaran pendidikan, program peningkatan kesejahteraan, meliputi: Biaya Operasional Sekolah (BOS dan BOSDA), pendidikan gratis, Bantuan Khusus Murid (BKM) dan Bantuan Siswa Miskin (BSM), partisipasi masyarakat, dan wajib belajar, penuntasan buta aksara dan peningkatan angka partisipasi pendidikan untuk jenjang pendidikan menengah.

\section{Kebijakan Pemerintah Daerah dalam Pembinaan Lembaga Pendidikan Islam di Kota Palopo Pengembangan kelembagaan}

Berdasarkan hasil observasi di lapangan, diperoleh data bahwa pada aspek ini telah terjadi perubahan ke arah perbaikan dan pengembangan pada lembaga pendidikan tersebut sesuai dengan prinsip-prinsip pengelolaan desentralisasi pendidikan. Hal ini dapat terlihat paling tidak pada dua hal penting, yaitu: 


\section{Restrukturisasi organisasi sekolah (satuan pendidikan)}

Pada madrasah dan sekolah obyek penelitian telah dilakukan restrukturisasi organisasi sebagai upaya penguatan dan pengembangan kelembagaan, antara lain; pengangkatan atau pengukuhan kepala madrasah/sekolah sebagai penanggung jawab satuan pendidikan dan dibantu oleh wakil kepala madrasah/sekolah, yang jumlahnya bervariasi dengan sesuai kebutuhan masing-masing madrasah/sekolah. Hal ini sesuai dengan struktur organisasi dan pengelolaan berdasarkan prinsipprinsip manajemen berbasis sekolah (pasal 49 ayat 1 dan pasal 50 ayat 1, 2, 3 huruf c, d, e PP No. 19 Tahun 2005 tentang Standar Nasional Pendidikan dan pasal 12 Perda Kota Palopo No. 02 Tahun 2013 tentang Pengelolaan dan Penyelenggaraan Pendidikan).

\section{Pembentukan komite sekolah}

Berdasarkan hasil penelitian, pada madrasah/ sekolah obyek semuanya telah memiliki lembaga komite sekolah yang merupakan wadah partisipasi masyarakat dalam pendidikan. Struktur organisasi dan mekanisme pemben-tukannya telah terlaksana berdasarkan undang-undang dan peraturan dengan semangat desentralisasi pendidikan (pasal 56 ayat 1 UU No. 20 Tahun 2003 tentang Sistem Pendidikan Nasional dan pasal pasal 44 ayat 2-7 dan pasal 45 ayat 1 Perda Kota Palopo No. 02 Tahun 2013 tentang Pengelolaan dan Penyeleng-garaan Pendidikan).

Akan tetapi berdasarkan data yang diperoleh di lapangan, komite sekolah yang dimaksud pada semua madrasah/sekolah obyek belum melaksanakan tugas dan fungsinya secara maksimal sesuai yang diamanahkan oleh undang-undang dan peraturan yang ada yaitu berperan dan berfungsi untuk meningkatkan mutu pelayanan dengan memberikan pertimbangan, arahan dan dukungan tenaga, sarana dan prasana, serta pengawasan pada satuan pendidikan bersangkutan (pasal 56 ayat 3 UU No. 20 Tahun 2003 tentang Sistem Pendidikan Nasional dan pasal pasal 44 ayat 1 dan pasal 45 ayat 1 Perda Kota Palopo No. 02 Tahun 2013 tentang Pengelolaan dan Penyelenggaraan Pendidikan). Hal ini dapat dilihat dalam format daftar isian tentang data dukung keorganisasian komite madrasah/ sekolah, pembentukan dan tata kerja. Namun, peran dan fungsi tersebut dilaksanakan baru sebatas pada kontribusi sarana-prasarana dalam jumlah sangat terbatas belum menyentuh pada upaya mewujudkan konsep pengembangan madrasah/sekolah ke depan. Hal ini pun hanya terjadi pada SMP dan SMA Pesantren Datuk Sulaiman yang merupakan lembaga pendidikan berbasis masyarakat yang dikelola secara khusus.

\section{Pendistribusian tenaga pendidik dan kependidikan}

Beradasarkan hasil penelitian diperoleh data bahwa pada madrasah/sekolah obyek menunjukkan bahwa jumlah guru yang dimiliki oleh MIS DDI sebanyak 17 orang dengan rincian 4 orang berstatus PNS Kemenag, 1 orang PNS Dikbud dan 12 orang guru honorer yayasan, melayani sejumlah 426 siswa. Ratio guru dan siswa berbanding 1: 25,05. Pada M.Ts.N. Palopo, jumlah guru sebanyak 59 orang, dengan rincian 28 orang berstatus PNS Kemenag, 15 orang berstatus PNS Dikbud dan 16 orang berstatus honorer. Melayani siswa berjumlah 1039 dengan ratio guru-siswa berbanding 1: 17,61. Pada SMP PMDS jumlah guru yang ada sebanyak 49 orang dengan rincian 1 orang PNS Kemenag, 15 orang PNS Dikbud dan 33 orang berstatus honorer yayasan, dengan ratio guru-siswa berbanding 1: 7,77. Sedangkan pada SMA PMDS jumlah guru yang ada sebanyak 39 orang dengan rincian PNS Dikbud 15 orang dan 24 orang berstatus honorer yayasan.

Berdasarkan data di atas tergambar bahwa ratio guru-siswa pada madrasah/sekolah obyek sangat ideal oleh karena mencapai bahkan melebihi target nasional yang menetapkan perbandingan 1: 25 sampai 30 orang. Hanya saja penyebaran guru pada bidang studi tidak merata, oleh karena dominan guru yang dimiliki berlatarbelakang pendidikan agama.

Selanjutnya, dilihat dari sisi pendistribusian guru Dikbud ke lembaga pendidikan Islam memang telah terlaksana, akan tetapi secara kuantitas masih tergolong minim dan tidak merata antara satu satuan pendidikan dengan yang lain, apalagi jika dibandingkan dengan sekolah-sekolah umum. Misalnya, antara MI DDI I Palopo, M.Ts.N. Palopo dan SMP-SMA PMDS Palopo. Hal ini terjadi, antara lain disebabkan oleh perbedaan status dan afiliasi kementerian, seba-gaimana dikemukakan oleh Drs.H.Ibnu Hajar (Kepala Madrasah DDI I Palopo) sebagai berikut:

Bahwa tiadanya atau kurangnya tenaga pengajar yang diberikan oleh Pemerintah Kota kepada madrasah disebabkan status madrasah sebagai satuan pendidikan yang berada di bawah afiliasi lembaga vertikal kementerian agama, 
berbeda dengan SMP dan SMA pesantren di satu sisi berada di bawah naungan kementerian agama, dan di sisi yang lain sebagai sekolah di bawah koordinasi kementerian pendidikan dan kebudayaan (wawancara, 10/6/2015).

Fenomena tersebut di atas menunjukkan perlakuan diskriminatif terhadap lembaga pendidikan Islam, khususnya madrasah. Hal ini bertentangan dengan prinsip penyelenggaraan pendidikan yang menganut prinsip kesetaraan, yakni "pendidikan pendidikan diselenggarakan sebagai suatu kesatuan yang sistemik dengan sistem terbuka dan multimakna" (pasal 4 ayat 2 UndangUndang Nomor 20 Tahun 2003). Artinya, antara satuan pendidikan dengan yang lainnya memiliki derajat yang sama dan memperoleh hak yang sama, termasuk dalam hal hal perolehan tenaga pendidik.

Dalam Undang-Undang disebutkan bahwa "pengangkatan, penempatan, dan penyebaran pendidik diatur berdasarkan kebutuhan satuan pendidikan formal. Pemerintah dan pemerintah daerah berkewajiban memfasilitasi tenaga pendidik dan kependidikan satuan pendidikan yang diperlukan untuk menjamin terselenggaranya pendidikan yang bermutu" (pasal 41 ayat 2 dan 3 Undang-Undang Nomor 20 Tahun 2003 tentang Sisdiknas). Kenyataan di atas, juga bertentangan dengan Perda Pendidikan Kota Palopo yang notabene adalah produk Pemerintah kota Palopo sendiri yang intinya menegaskan bahwa adalah "kewajiban dan tanggungjawab Walikota untuk mengatur dan menata penempatan tenaga pendidik dan kependidikan pada satuan pendidikan secara merata dan berkeadilan." (pasal 25 ayat 3 Perda Kota Palopo No. 2 Tahun 2003 tentang pengelolaan dan penyelenggaraan pendidikan).

\section{Pembinaan sumber daya manusia (SDM)}

Berdasarkan hasil penelitian diperoleh data bahwa semua madrasah/sekolah obyek telah mendapatkan pembinaan baik langsung maupun tidak langsung dari pemerintah kota melalui Dinas Dikbud Kota, baik kegiatan yang diprogramkan secara berkala, maupun yang bersifat insidental. Program kegiatan pembinaan yang dimaksud antara lain: penataran keterampilan/ metode pengajaran bagi para guru, optimalisasi peran dan pemberdayaan gugus sekolah melalui kelompok kerja guru (KKG), musyawarah guru mata pelajaran (MGMP), kelompok kerja kepala sekolah (KKKS), musyawarah kerja kepala sekolah (MKKS), penyusunan materi ujian sekolah, dan kegiatan peningkatan mutu pendidikan lainnya (wawancara dengan Gazali Rahman, 21/6/2013). Hal ini sesuai amanah yang tertuang dalam perda pendidikan nomor 11 tahun 2008 pasal 10 ayat 2 . Dengan demikian, dari aspek ini pembinaan SDM pada lembaga pendidikan Islam melalui dua jalur pembinaan yaitu, jalur pembinaan yang dilakukan oleh Kementerian Agama Kota Palopo sebagai kementerian vertikal yang membidangi lembaga pendidikan Islam dan jalur pembinaan Pemerintah Daerah/Kota. Dengan begitu mutu output dan proses layanan pendidikan Islam dapat lebih berkualitas melebihi dari pada lembaga pendidikan lainnya pada masa mendatang.

\section{Pengembangan sarana dan prasarana}

Sebagian besar madrasah hampir tidak pernah mendapatkan subsidi berupa penambahan atau rehabilitasi sarana-prasana atau fasilitas lain, kecuali pada masa awal penerapan kebijakan desentralisasi pendidikan. Itupun dalam jumlah terbatas dan bersifat insidental. Hal ini sesuai dengan pernyataan St. Bahriah, S.Ag, sebagai berikut: "bahwa bantuan Pemkot ke madrasah kami berupa sarana prasarana dalam bentuk rehabilitasi gedung kelas dan meubeleir terjadi pada priode tujuh atau delapan tahun yang lalu, setelah itu tidak ada lagi kecuali dana pendidikan gratis" (wawancara, $10 / 6 / 2015)$.

Berbeda halnya dengan SMP dan SMA Pesantren Modern Datok Sulaiman kedua lembaga ini sering mendapatkan bantuan dari Pemerintah Kota Palopo dalam porsi yang cukup memadai, meskipun harus diakui subsidi tersebut belum maksimal dan tidak sebanding dengan apa yang diberikan kepada sekolah-sekolah umum negeri (hasil wawancara dengan Mustami, 15/6/2015). Adapun subsidi yang diberikan biasanya disesuaikan dengan permohonan dan analisa kebutuhan yang tergambar dalam laporan berkala untuk setiap tahun anggaran dalam bentuk dana blockgrant, DAK; antara lain RKB baru, rehabilitasi, mubeleir, buku-buku perpustakaan, perangkat pembelajaran elektronik dan bantuan lainnya. Selain itu, juga bantuan dalam bentuk rekomendasi untuk memfasilitasi bantuan dari pihak ketiga, misalnya subsidi dari Dinas Koperindag Kota untuk Kopontren (Koperasi Pondok Pesantren) dalam bentuk peralatan mesin jahit untuk produksi keterampilan siswa/santriwati; bantuan bangungan MCK plus dari kerjasama Pemkot Palopo, BORDA dan Balifocus (hasil wawancara dengan H. Bennuas, 
16/6/2015). Meskipun bantuan yang disebutkan di atas adalah untuk pesantren secara umum, akan tetapi yang lebih banyak menggunakan adalah siswa SMP dan SMA karena mereka adalah merupakan tingkatan peserta didik yang tinggal di asrama.

Dalam konsep paradigma baru pendidikan yang menganut prinsip kesetaraan dan keseimbangan tidak dikenal lagi istilah satuan pendidikan "plat merah atau plat kuning". Semuanya berhak memperoleh dana dari negara atau pemerintah dan pemerintah daerah dalam suatu sistem terpadu. Demikian juga adanya kesetaraan antara satuan pendidikan yang dikelola oleh Kementerian Pendidikan dan Kebudayaan dengan satuan pendidikan yang dikelola oleh Kementerian Agama yang memiliki ciri khas tertentu. Undangundang Sisdiknas telah menempatkan pendidikan sebagai satu kesatuan yang sistemik (pasal 4 ayat 2 UU No. 20 Tahun 2003).

Terjadinya kesenjangan dalam distribusi sebagaimana disebutkan di atas, menurut hemat peneliti bukanlah sepenuhnya merupakan kesalahan Pemerintah Kota c.q. Dinas Kemendikbud Kota Palopo, melainkan juga disebabkan kekurang aktifan pihak madrasah dalam melakukan komunikasi dengan pihak pemerintah daerah. Mereka terkesan hanya menunggu bola, tidak proaktif menjemput bola. Padahal mekanisme prosedur yang diterapkan oleh pemerintah kota adalah setiap satuan pendidikan yang membutuhkan subsidi harus mengajukan Rencana Kegiatan Anggaran Sekolah (RKAS) kepada Dinas Pendidikan untuk dibahas secara bersama dengan Dewan Pendidikan dan Komite Sekolah (pasal 37 ayat 1-5 Perda No. 2 Tahun 2013).

\section{Subsidi pendanaan dalam rangka peningkatan kesejahteraan.}

Berdasarkan hasil penelitian pada sekolah/ madrasah sampel, diperoleh data satuan pendidikan madrasah (MI DDI dan M.Ts.N) tidak mendapatkan dana BOS dari pemerintah kota. Hal ini didasari oleh pertimbangan bahwa kedua satuan pendidikan Islam tersebut telah menerima dana BOS melalui Kementerian Agama, sebagai kementerian yang membawahinya. Sehingga untuk menghindari terjadinya penerimaan ganda, maka kedua satuan pendidikan dimaksud tidak berhak untuk mendapatkan dana BOS dari pemerintah kota. Sedangkan, SMP Pesantren Datok Sulaiman sebagai bagian dari sistem pendidikan dasar Islam yang berafiliasi pada Kementerian Pendidikan
Kebudayaan menerima dana tersebut dari pemerintah kota. Adapun SMA Pesantren Datok Sulaiman tidak mendapatkan anggaran dana BOS hingga tahun 2013. Kecuali, nanti setelah semester awal tahun anggaran 2014 mendapatkan dana BOSDA (Biaya Operasional Sekolah Daerah) yaitu anggaran biaya untuk operasional sekolah khusus untuk tingkat SLTA yang murni bersumber dari APBD Kota Palopo. Konsekuensi dari kebijakan BOSDA ini yang sumber penganggarannya murni dari ABPD kota Palopo sendiri, maka statusnya sangat tergantung dari kondisi kemampuan keuangan daerah.

Selanjutnya, khusus untuk SMP dan SMA Pesantren Sulaiman, selain telah memperoleh dana BOS dan BOSDA dalam jumlah cukup memadai, namun masih memperoleh anggaran dari sumber lain dalam kaitannya dengan penerapan boarding school yang dilakukan oleh pihak yayasan. Oleh karena itu, untuk pembiayaan kedua satuan pendidikan tersebut, baik SMP maupun SMA, pihak yayasan PMDS menggalang dana pembiayaan pendidikan dari masyarakat, terutama orangtua santri. Dana yang digalang dari masyarakat terdiri atas dua jenis, yaitu: berupa sumbangan pembangunan sebesar Rp. 3.000.000,- persantri baru, dan pembayaran bulanan sebesar Rp. 500.000,- persantri untuk setiap bulannya. Selain itu, pihak yayasan juga menggalang dana dari para dermawan/ donatur dalam bentuk sumbangan yang tidak mengikat.

Semua madrasah/sekolah sampel mendapatkan dana pendidikan gratis dan alokasi penggunaannya telah dilakukan sesuai ketentuan yang berlaku. Dengan adanya program ini sangat membantu dan memberi stimulus yang besar bagi aktifitas pendidikan pada lembaga pendidikan Islam. Hal ini dapat terlihat pada peningkatan partisipasi dan animo masyarakat terhadap lembaga pendidikan Islam, juga pada mutu, layanan, pelaksanaan proses pembelajaran serta peningkatan kesejahteraan tenaga pendidik dan tenaga kependidikan.

Hanya ada dua satuan pendidikan Islam yang mendapatkan alokasi subsidi dana BKM atau BSM alokasi subsidi dana BKM atau BSM, yaitu SMP dan SMA Pesantren Datok Sulaiman, sedangkan MI DDI I Palopo dan M.Ts.N. Palopo tidak mendapatkan. Dan pada satuan pendidikan yang mendapatkan dana tersebut juga terdapat perbedaan besaran nominal. Perbedaan tersebut didasarkan pada perbedaan tingkat jenjang persekolahan. Sedangkan jumlah besaran siswa 
yang menerima bantuan didasarkan pada usulan masing-masing sekolah sesuai jumlah siswa yang memenuhi kriteria sebagai siswa penerima dana bantuan, dan juga pertimbangan keterse-diaan dana Pemerintah Kota.

Fenomena terjadinya kesenjangan pengalokasian dana BKM atau BSM tersebut di atas yang hanya diberikan kepada satuan pendidikan tertentu, bertentangan dengan Peraturan Pemerintah dan Peraturan Pemerintah Daerah yang menetapkan tentang kewajiban pemerintah dan pemerintah daerah menyiapkan dan memberikan bantuan bagi siswa miskin dan tidak mampu (pasal 31 ayat 1-2, Perda Kota Palopo No. 11 Tahun 2008), dan (pasal 12 ayat 1 huruf c UU No. 20 Tahun 2003).

Berdasarkan informasi yang diperoleh dari para pihak, peneliti menyimpulkan bahwa hal tersebut di atas terjadi, disebabkan oleh karena adanya miskomunikasi antara satuan pendidikan/ madrasah dengan pihak leader sector pendidikan yaitu Dinas Dikbud Kota. Sesuai prosedur yang ada bahwa untuk mendapatkan subsidi dana BKM atau BSM satuan pendidikan bersangkutan harus mengajukan permohonan sebagai bahan pertimbangan bagi Dinas Dikbud, dan hal ini yang kurang mendapat perhatian oleh mereka.

Sebagian besar guru, terutama yang berstatus PNS telah bersertifikasi dan beberapa orang di antaranya berstatus non PNS. Dalam hal pembayaran tunjangan sertifikasi ini dilakukan oleh masing-masing kementerian yang mengSK-an guru yang bersangkutan termasuk yang berstatus DPK, kecuali guru agama. Pada guru agama terjadi advantage bagi Pemerintah Kota, karena guru agama yang notabene pengangkatan Pemerintah Kota pembayaran tunjangannya tidak dibayarkan oleh Peme-rintah Kota, akan tetapi melalui anggaran Kementerian Agama.

Kebijakan program sertifikasi ini memberi implikasi yang sangat berarti bagi lembaga Pendidikan Islam. Paling tidak dapat dilihat pada dua hal yaitu pertama; terjadinya distribusi kesejahteraan bagi para tenaga pendidik, dan kedua; dengan distri-busi kesejahteraan tersebut, maka mutu layanan pendidikan semakin tertib dan meningkat jika dibandingkan dengan masa-masa sebelumnya.

\section{Pengawasan}

Dalam manajemen pendidikan kegiatan pengawasan adalah suatu hal yang sangat penting, karena merupakan tindakan untuk mengukur dan mengontrol sejauhmana efisiensi dan efektifitas penyelenggaran pendidikan tersebut berproses. Dalam Peraturan Pemerintah Nomor 19 Tahun 2005 tentang SNP disebutkan bahwa pengawasan terhadap satuan pendidikan meliputi; kegiatan pemantauan, supervisi, evaluasi, dan tindaklanjut hasil pengawasan, dilakukan oleh pihak internal dan eksternal pelaku dan pemerhati pendidikan. Aspek yang disupervisi meliputi aspek manajerial dan aspek akademik yang dilakukan secara teratur dan berkesinambungan (pasal 55-57).

Sehubungan dengan itu, dalam konteks desentralisasi pendidikan, maka lembaga pendidikan Islam di Kota Palopo menghadapi beberapa pengawasan baik secara internal maupun ekstenal secara berkala. Sebagai satuan pendidikan yang berada di bawah naungan kementerian vertikal, mendapatkan pengawasan dari Kementerian Agama, dan sebagai institusi pendidikan berada dalam wilayah otonomi daerah mendapatkan pengawasan dari pemerintah daerah. Selain itu, juga diawasi oleh pihak komite sekolah dan lembaga pemerhati pendidikan lainnya.

Jenis pengawasan meliputi beberapa aspek, terutama yang terkait dengan aspek manajerial dan aspek akademik, meliputi: pengawasan atas subsidi yang bersifat sarana-prasana dan finansial yang dilakukan oleh masing-masing pihak yang memberikan subsidi dalam hal ini Kementerian Agama dan Pemerintah Kota Palopo melalui Dinas Dikbud; proses pembelajaran, kurikulum atau silabi, persiapan mengajar guru, manajemen sekolah, tertib dan disiplin pegawai dan guru, dan lain-lain dalam kaitan pengembangan dan peningkatan mutu lembaga.

Berdasarkan uraian pada anak sub bab di atas, dapat dipahami bahwa proses pelaksanaan desentralisasi pendidikan di Kota Palopo dalam kaitannya dengan Lembaga Pendidikan Islam telah berjalan on the track. Problema yang muncul dalam beberapa hal mengenai proses kebijakan tersebut yang menye-babkan hadirnya kesan diskriminatif terhadap lembaga pendidikan Islam, antara lain disebabkan oleh terjadi kurangnya komunikasi dan keaktifan para pihak terkait antara Pemerintah Kota dan satuan pendidikan Islam itu sendiri dalam mensosialisikan dan merespons issu berkaitan dengan kebijakan desentralisasi pendidikan tersebut.

Bagi satuan pendidikan Islam, terutama pengelola madrasah, dalam konteks otonomi daerah muncul pada diri mereka perasaan risih atau grogi 
sebagai akibat dari institution problem yang mereka alami, karena secara formal kelembagaan mereka berada di bawah naungan Kementerian Agama yang bersifat vertikal, dan pada sisi yang lain mereka berada pada wilayah otonom yang menganut sistem desentralisasi dalam pengelolaan pendidikan. Sehingga dengan demikian menjadi persoalan tersendiri bagi mereka dalam rangka menyesuaikan diri dan merespon kebijakan-kebijakan pendidikan pemerintah kota, sebagaimana halnya yang dilakukan oleh satuan pendidikan yang berada di bawah naungan Kementerian Pendidikan dan Kebudayaan.

\section{PENUTUP}

Berdasarkan uraian tersebut di atas, dapat ditarik beberapa kesimpulan sebagai berikut:

Pelaksanaan desentralisasi pendidikan di Kota Palopo telah telah berjalan sebagaimana mestinya; meliputi beberapa aspek, yaitu: penguatan kelembagaan, penjaminan mutu dan akreditasi, pengembangan sarana dan prasarana, pembinaan dan pengembangan sumber daya manusia (SDM), peningkatan kesejahteraan, pendidikan gratis, peningkatan partisipasi masyarakat, dan aspekaspek lainnya terkait dengan kebijakan pemerintah di bidang pembangunan pendidikan.

Pelaksanaan desentralisasi pendidikan memberi dampak positif terhadap lembaga pendidikan Islam di Kota Palopo, walaupun dalam beberapa hal belum maksimal. Hal tersebut dapat dilihat pada beberapa aspek, sebagai berikut: a) Pengembangan lembaga, b) Distribusi tenaga pendidik dan pembinaan Sumber Daya Manusia (SDM). Dalam hal pendistribusian tenaga pendidik dan kependidikan terjadi kebijakan diskriminatif Pemerintah Kota antara lembaga pendidikan Islam khususnyamadrasahdenganpendidikanumumyang berada di bawah naungan Kementerian Pendidikan dan Kebudayaan. c) Aspek Pengembangan Sarana-Prasarana dan Fasilitas terjadi perlakuan diskriminatif Pemerintah Kota antara lembaga pendidikan Islam (madrasah) dan lembaga pendidikan yang berada di bawah naungan Dikbud. d) Subsidi pendanaan dalam rangka peningkatan kesejahteraan terjadi diskriminasi antara madrasah dan sekolah di bawah naungan Pendidikan dan Kebudayaan. Pada madrasah hanya mendapatkan Dana Pendidikan Gratis (DPG), sedangkan sekolah Dikbud termasuk SMP dan SMA Pesantren Datok Sulaiman, selain mendapatkan Dana Pendidkan
Gratis (DPG), juga memperoleh dana Bantuan Khusus Murid (BKM) yang diperuntukkan bagi peserta didik yang miskin-berprestasi. e) Dalam hal Pengawasan, Dinas Pendidikan Kebudayaan melakukannya kepada seluruh sekolah/madrasah termasuk kepada lembaga pendidikan swasta. Jenis pengawasan, adalah yang berkaitan dengan aspek akademik dan manajerial.

\section{DAFTAR KEPUSTAKAAN}

Abdurrahmansyah. 2005. Wacana Pendidikan Islam, Cet. I. Yogyakarta: Global Pustaka Utama.

Alihsyahbana, Armida S. 2000. Otonomi Daerah dan Desentralisasi Pendidikan (Makalah). Bandung, 4 April, 2000.

Andi Malla, Hamlan AB. Kebijakan Pemerintah tentang Madrasah, Posisi Madrasahdalam Konfigurasi Sistem Pendidikan Nasional 1945-2005.

Departemen Agama RI, Pedoman Life Skills dalam Pembelajaran Madrasah Aliyah (Dokumen), Direktorat Jenderal Kelembagaan Agama Islam, 2005.

Departemen Pendidikan Nasional RI. 2001. Desentralisasi Pendidikan, Jakarta: Komisi Nasional Pendidikan.

Jamaluddin. 2001. "Kebijakan Desentralisasi Pendidikan Menengah di D.I.Aceh" dalam Khaeroni, et.al, Islam dan Hegemoni Sosial, Cet.I; Jakarta: Direktorat Perguruan Tinggi Agama Islam Departemen Agama RI.

Miftah, Toha. "Desentralisasi Pendidikan", Jurnal Dikbud No.017, Juni 1999.

Mariman Darto. 2008. Prospek danTantangan Desentralisasi Pendidikan di Kalimantan Timur (Ringkasan Hasil Penelitian), (2008).

Prawira,Sugianto, Kebijakan Pendidikan di Era Otonomi Daerah dan Pengaruhnya Terhadap Perencanan Pendidikan (Makalah).

Republik Indonesia, "Undang-Undang No. 32 Th. 2004 tentang Pemerintah Daerah 2004"Jakarta: Sinar Grafika, 2005.

Republik Indonesia, Undang-Undang Republik Indonesia Nomor 20 Tahun 2003 tentang Sistem Pendidikan Nasional dihimpun dalam UndangUndang Pemerintah RI tentang Pendidikan, Jakarta: Direktorat Jenderal Pendidikan Islam Departemen Agama RI, 2006.

Republik Indonesia, "Undang-Undang Nomor 20 Tahun 2003 tentang Sistem Pendidikan Nasioanal".

Syafaruddin, Manajemen Lembaga Pendidikan Islam, Cet. I; Jakarta: Ciputat Press, 2005.

Zayadi, Ahmad Zayadi, et, al, Desain Pengembangan Madrasah (Dokumen), Departemen Agama RI Direktorat Jenderal Kelembagaan Agama Islam, 2005. 